\title{
The Creation of a Champagne Brand*
}

\author{
Enrico Baldin $^{* *}$
}

\begin{abstract}
The history of Champagne Encry is marked by the courage and the strong desire to embark on a journey that makes us unique in the world of Champagne. The art of making Champagne has grown together with the value of our wines and merged wisely with the emotion and passion to create the finest champagne Encry.
\end{abstract}

Keywords: Champagne; Luxury Industry; Global Markets; Global Competition; Luxury Brand; Encry

\section{Love, Art, Passion and Courage}

The history of Champagne Encry is marked by the courage and the strong desire to embark on a journey that makes unique in the world of Champagne. A plan with an exquisitely elegant and dynamic profile as we believe that the wine expresses the soul of the people who make it.

Every year our mission is to create the perfect cuvée selecting only the finest grapes that can give our wine such a unique tasting profile, not following too many rules of thumb, but our palate, the symphony we use to play reaches such high level that other comparative practices aren't adequate. The art of making Champagne has grown together with the value of our wines and merged wisely with the emotion and passion to create the finest champagne Encry.

Love, Art, Passion and Courage are at the core of the Maison de Champagne Veuve Blanche Estelle with the great cuvée 'ENCRY'. A story, even the simplest, marks its time through the courage of some choices, the desire to achieve, the ability to design, the attention to details.

We interpret our time through the different techniques that characterise our reality and go ahead facing the future as you face a challenge full of pitfalls and overcoming our power. Nothing is absurd when you come to broaden your horizons.

\section{The Champagne Encry}

Together with my life \& work-partner, Nadia, we developed the passion to create a great champagne together with our 'vigneron'. I have always been in love with

\footnotetext{
* Invited Article

** General Manager, Champagne Encry (info@champagne-encry.com)
} 
wine bubbles, even though my main business focuses on bioengineering and environmental restoration. Indeed, I gained experience in using a system called 'hydroseeding', a process that entails the usage of special blends of natural products, including a mix of selected seeds to restore the original habitat.

This fact has led me to work for a vineyards business in Tuscany and then to join multiple renowned wineries in Champagne. Stated the hard task of preventing wine yards' erosion and providing oxygen to the grape-vine roots to bring better yield grapes, this cultivation technique has been applied to these Champagne grape-vines and has led me to start the Encry project. The adventure began in the village of Le Mesnil-sur-Oger, in France, in 2004. It is located in one of the most flourishing areas of Champagne, where the grey limestone soil (also known as Kimmeridgian) provides unique features to its grapes, helps us to produce the finest cuvee Champagne. In 2005, there was the first harvest and the birth of our first Cuvée Brut Blanc de Blancs, 100\% Chardonnay, and consequently, the Millésime 2005 Blanc de Blancs in that year of vintage.

The cave in which the vigneron makes its wine, was initially made with simple stones and plasters with cement barrels, as dictated by the real tradition of Champagne. Thanks to our work, the cave has turned into a modern laboratory where stainless steel barrels are deployed to monitor the wine temperature at each stage of fermentation.

Once labelled the first bottles, we sent wine samples to the CIVC (Comite Interprofessionnel du Vin de Champagne) to request their approval. However, when we recently sent the new and modern labels (the current black ones) to the CICV, these latter unexpected blocked the process as no Maison existed and was ascribable to Champagne Encry.

The fate was on our side as one of the vigneron's relative in 1917 invented and created the 'Maison Blanche Estelle' in an attempt to sell champagne abroad. The registration of the House in the data-processing of the CIVC, never exploited before, was readily transferred from the vigneron to Nadia and, as well as in any self-respecting fairy tale, the happy ending was sealed by the presence of a new lady, Nadia, in the list of the owners of Champagne Maisons.

In order to go ahead, we inserted in the label the lettering Veuve Blanche Estelle where 'veuve' literally 'widow', means the transfer of a Maison from one to another. The name, 'ENCRY' derives from my nickname 'Enry' plus the letter ' $C$ ' meaning 'Champagne'. Thus, the Maison was registered as Veuve Blanche Estelle and was included among the récoltants - manipulants (i.e. farmers-managers). The mention of RM, which is on the label, symbolises those small producers who collect, produce and sell wines directly.

The Maison aims at carrying on the champagne production in order to capture and attract those consumers who are looking for 'ENCRY' features. Furthermore, it means not only the prestige of a Grande Cuvée but also a product excellent in taste and elegance.

\section{The Product Assortment}

The Cuvée are presently exported overseas and to Europe. In particular, to the U.S., Canada, England, Czech Republic and soon to China and Japan. In Italy we have small companies that have discovered and embraced Encry' philosophy. We 
aim to establish our presence abroad and to impose it as well in Italy in the HORECA luxury sector.

A brief description of our main cuvee follows.

Brut: This is the first cuvée made by our company with $100 \%$ Chardonnay grapes classified as Grand Cru. It has spent at least 36 months on the lees. The nose is appealing with hints of peach and pear on the surface, sweet citrus, white flowers, anise, almond nuances of honey and a soft background upon a solid framework toasted and mineral.

Zero Dosage: This cuvée is made with $100 \%$ chardonnay grapes. It has spent at least 36 months on the lees. It's an expression of the pure soil of Le Mesnil-surOger. We can perceive the marine fossils, the elegance and the subtlety of the gypsum given by the land itself. Its aroma is a sharp knife, mineral and scratchy.

Millésime 2004 and 2005: The first cuvee, Millesime 2004, is made with 100\% Chardonnay grapes and it has spent at least 6 years on the lees. In this millésime we have a silky elegance blends with an intense aromatic accuracy. The colour is bright yellow with light amber tones on the nose that precede a rich bouquet of white fruits and the mineral purity of the Grand Cru Le Mesnil-sur-Oger.

The second cuvee is made with $100 \%$ Chardonnay grapes and it has spent at least 5 years on the lees. The nose is intense and complex with scents of herbs, spices, candied citrus, cedar and ginger, all on a toasted wrap. The plot of wine is woven by the threads of a mineral presence and pinch of dry fruits that are arranged on a long finish that close the tasting with an elegant and toasted wake.

Grande Rosé: This cuvée is made with 95\% chardonnay grapes and 5\% of pinot noir. It has spent at least 36 months on the lees. In this blend there is an encroachment on another Grand $\mathrm{Cru}$ area. The vin rouge requested for the production of the rosé wine type, comes from Bouzy. Anyway this wine is most peculiar already from the delicate colour not as intense and noisy as many other use to be.

\section{Bibliography}

Beverland, M. (2004). Uncovering 'theories-in-use': building luxury wine brands. European Journal of Marketing, 38(3/4), 446-466.

http://dx.doi.org/10.1108/03090560410518648

Beverland, M. (2006). The 'real thing': Branding authenticity in the luxury wine trade. Journal of Business Research, 59(2), 251-258.

http://dx.doi.org/10.1016/j.jbusres.2005.04.007

Brondoni, S.M. (2014). Global Capitalism and Sustainable Growth. From Global Products to Network Globalisation, Symphonya. Emerging Issues in Management (symphonya.unimib.it), 1, $10-31$.

http://dx.doi.org/10.4468/2014.1.02brondoni

Brondoni, S.M., Corniani, M., \& Riboldazzi, S. (2013). Global Retailers, Market-Driven Management and Innovation. The International Journal of Economic Behavior-IJEB, 3(1), 27-40. 
Cesarani, M. (2014). Competitive Dimension of Outsourcing Relations in Global Networks. Journal of Management Policies and Practices, 2(4), 97-112.

http://dx.doi.org/10.15640/jmpp.v2n4a5

Charters, S., \& Spielmann, N. (2014). Characteristics of strong territorial brands: The case of champagne. Journal of Business Research, 67(7), 1461-1467.

http://dx.doi.org/10.1016/j.jbusres.2013.07.020

Deroy, X., \& Thénot, M. (2015). L'évolution des logiques coopérative et de marché dans les coopératives agricoles françaises. Le cas de Champagne Céréales. Revue française de gestion, 41(250), 31-47.

Dollet, J. N., \& Matalobos, A. D. (2010). Network orchestration in response to customized mass markets of premium wines and spirits. In Supply Chain Forum: An International Journal 11(1), 64-74. Taylor \& Francis.

Gnecchi, F. (2013). Retailing, Private Label and Global Competition, Symphonya. Emerging Issues in Management (symphonya.unimib.it), 2, 79 - 87.

http://dx.doi.org/10.4468/2013.2.06gnecchi

Lambin, J.J. (2014). Rethinking the Market Economy. Symphonya. Emerging Issues in Management (symphonya.unimib.it), (2), 4-15.

http://dx.doi.org/10.4468/2014.2.02lambin

Kniazeva, M., \& Charters, S. (2014). Authenticity in the Mirror of Consumer Memories, or Drinking Champagne in Russia. Brand Management in Emerging Markets: Theories and Practices, Hershey, PA: IGI Global, 121-136. http://dx.doi.org/10.4018/978-1-4666-6242-1.ch007

Ody-Brasier, A., \& Vermeulen, F. (2014). The Price You Pay Price-setting as a Response to Norm Violations in the Market for Champagne Grapes. Administrative Science Quarterly, 59(1), 109144.

http://dx.doi.org/10.1177/0001839214523002

Riboldazzi, S. (2005). Global Retailers and Competitive Customer Value. Symphonya. Emerging Issues in Management (symphonya.unimib.it), 2, 77-87.

http://dx.doi.org/10.4468/2005.2.07riboldazzi

Salvioni, D.M., \& Boselli L. (2014). Sustainable Development and Corporate Communication in Global Markets, Symphonya. Emerging Issues in Management (symphonya.unimib.it), 1, 32-51. http://dx.doi.org/10.4468/2014.1.03salvioni.bosetti

Sgard, J. (2015). Global economic governance during the middle ages: The jurisdiction of the champagne fairs. International Review of Law and Economics, 42, 174-184.

http://dx.doi.org/10.1016/j.irle.2013.08.001

Sjostrom, T., Corsi, A. M., \& Lockshin, L. (2014). Consumer perceptions of premium and luxury wine brands. Wine \& Viticulture Journal, 29(3), 68.

Tresca, R. (2013). Global Business Networks and the Competitiveness of SMEs, Symphonya. Emerging Issues in Management (symphonya.unimib.it), (2), 67-78.

http://dx.doi.org/10.4468/2013.2.05tresca

Williams, A., \& Atwal, G. (2012). 21 The Hedonistic Consumption of Luxury and Iconic Wines. Luxury Marketing: A Challenge for Theory and Practice, 379. 